\title{
PLANNING ORTHODONTIC FRONTAL TEETH INCLINATION AND ESTIMATING BONE THICKNESS FROM CONE-BEAM COMPUTED TOMOGRAPHY IMAGES
}

Kopetskiy IS ${ }^{1}$, Meskhiya NG ${ }^{\otimes}$, Kopetskaya $\mathrm{Al}^{1}$, Eremin DA¹, Orekhova DD²

${ }_{1}$ Piragov Russian National Research Medical University, Moscow, Russia

${ }^{2}$ Lomonosov Moscow State University, Moscow, Russia

Changing the vestibulo-oral inclination (torque) of the frontal teeth is an important component of orthodontic treatment. Cone-beam computed tomography is recommended as an accurate diagnostic tool allowing the orthodontist to estimate the safety of frontal tooth movement and inclination. This tool is helpful in measuring bone thickness at different levels of the tooth root and estimating incisal inclination and position. The aim of our study was to analyze bone thickness in patients with pathologically and normally inclined teeth using CT images and to create a universal table that will provide useful information about the thickness of the bone around different segment of the root required for a safe change in tooth inclination. Using the proposed table, the orthodontist can assess the feasibility of the planned tooth movement in the setting of changed tooth inclination, with due account of critical bone deficit regions. This will ensure the safety of tooth movement, stable retention and a positive treatment outcome.

Keywords: orthodontic treatment, bone thickness, $\mathrm{CBCT}$, center of resistance, torque

Author contribution: Kopetskiy IS analyzed the literature; Meskhiya NG conducted the study, gathered and analyzed clinical data; Kopetskaya Al processed and analyzed source medical records; Eremin DA, Orekhova DD performed data analysis.

Compliance with ethical standards: the study was approved by the Ethics Committee of Piragov Russian National Research Medical University (Protocol No.116 dated March 26, 2012); informed consent was obtained from all study participants or their legal representatives.

$\triangle$ Correspondence should be addressed: Nana G. Meskhiya

Ostrovityanova, 1, Moscow, 117997; nilipelka@gmail.com

Received: 16.03.2021 Accepted: 05.04.2021 Published online: 27.04.2021

DOI: $10.24075 /$ brsmu.2021.015

\section{ИЗМЕНЕНИЕ ТОРКА ФРОНТАЛЬНЫХ ЗУБОВ С ОЦЕНКОЙ ТОЛЩИНЫ КОСТНОЙ ТКАНИ НА КОНУСНО-ЛУЧЕВОМ КОМПЬЮТЕРНОМ ТОМОГРАФЕ}

\author{
И. С. Копецкийㄱ, Н. Г. Месхия ${ }^{\otimes}$, А. И. Копецкая ${ }^{1}$, Д. А. Еремин ${ }^{1}$, Д. Д. Орехова²
}

1 Российский национальный исследовательский медицинский университет имени Н. И. Пирогова, Москва, Россия

${ }^{2}$ Московский государственный университет имени М. В. Ломоносова, Москва, Россия

\begin{abstract}
Изменения вестибуло-орального положения фронтальных зубов (торка) - важный этап в ортодонтическом лечении. Для наиболее точной диагностики, обеспечивающей врачу-ортодонту безопасное перемещение и изменение наклона фронтальной группы зубов, рекомендовано использовать конуснолучевую компьютерную томографию. Данная методика позволяет оценить толщину костной ткани на различных уровнях корня исследуемого зуба, измерить длину корней фронтальных зубов, определить наклон и положение резцов. Целью исследования было с помощью компьютерных томограмм пациентов с патологическими и физиологическими наклонами зубов провести анализ толщины костной ткани и разработать универсальную таблицу, использование которой даст врачу-ортодонту сведения о необходимой толщине костной ткани в различных сегментах корня при изменении вестибулоорального наклона. Используя данную таблицу, врач может оценить возможность запланированного перемещения зуба при изменении торка, приняв во внимание зоны критического десицита кости, что обеспечит безопасное перемещения зуба, стабильную ретенцию и благоприятный исход ортодонтического лечения.
\end{abstract}

Ключевые слова: ортодонтическое лечение, толщина костной ткани, КЛКТ, центр сопротивления, торк зуба

Вклад авторов: И. С. Копецкий - анализ литературы; Н. Г. Месхия - проведение исследования, сбор и анализ данных, А. И. Копецкая - обработка и анализ первичной документации; Д. А. Еремин - анализ данных; Д. Д. Орехова - анализ данных.

Соблюдение этических стандартов: исследование одобрено этическим комитетом РНИМУ им. Н. И. Пирогова (протокол № 116 от 26 марта 2012 г.); все участники исследования или их представители подписали добровольное информированное согласие.

$\bigotimes$ Для корреспонденции: Нана Гурамовна Месхия ул. Островитянова, д. 1, г. Москва, 117997; nilipelka@gmail.com

Статья получена: 16.03.2021 Статья принята к печати: 05.04.2021 Опубликована онлайн: 27.04.2021

DOI: $10.24075 /$ vrgmu.2021.015

While developing an orthodontic treatment plan, a dentist should consider a number of factors that may affect the outcome, such as the age of the patient, their growth potential, sex, and health conditions. Other important factors to look at include the mechanics of tooth movement and the center of resistance, tooth inclination, tooth vitality, and the thickness of the surrounding bone tissue $[1,2]$. The concept of the center of resistance was first introduced in 1917 by Fish, who proposed that there is a point in a free object through which an applied force will pass to move the object linearly without rotating it; this point is a point of equilibrium. A tooth is not a free object since it is surrounded by periodontal tissue. So, where its center of resistance is located depends on the length of its root, the number of roots it has and the amount of the surrounding bone tissue [3]. Research studies have demonstrated that the center of resistance of a single-rooted tooth surrounded by bone tissue lies $1 / 4-1 / 3$ of the distance between the cementoenamel junction and the root apex [3-5].

While planning to change the vestibulo-oral inclination of a front tooth, it is important to account for the bone thickness around it $[6,7]$. Accurate predictions of tooth movement will help to avoid complications that might arise in patients with insufficient bone volume. Dental radiography is a widely used imaging modality for diagnosing dental anomalies [8]. Cone- 
beam computed tomography (CBCT) is a diagnostic tool that allows measuring lingual/palatal and vestibular bone thickness at different levels of the tooth root and therefore can aid orthodontic treatment planning [8]. The planned tooth movements can pose a risk for the patient in the absence of CBCT data about the thickness of bone tissue surrounding the root [9-11]. Using CBCT images of the front teeth and the technique proposed in this article, an orthodontist can accurately determine the degree of inclination and the position of incisors, measure the amount of bone surrounding the root, predict the ultimate position of the root after tooth movement and thus avert some complications associated with bone tissue deficit.

The aim of the study was to develop an original universal CBCT-based technique for measuring bone thickness around the front teeth that can be employed to safely change the vestibulo-oral inclination (torque) of the front teeth.

\section{METHODS}

The analysis focused on teeth 1.3-2.3 and 3.3-4.3 in the frontal segment. A total of 106 CBCT images of dentistry patients aged 20 to 35 years were analyzed. The following inclusion criteria were applied: dental or jaw bone abnormalities in the frontal segment in the sagittal plane; absence of cardiovascular or endocrine disorders; absence of blood disorders. Exclusion criteria: age below 20 and above 35 years, pregnancy, breastfeeding, somatic pathology, cardiovascular, endocrine or blood disorders, systemic osteoporosis, smoking. Of all the participants, 45 (44.6\%) were male and 61 (55.4\%) were female. The analyzed CBCT images were sorted into 3 groups: images showing normally inclined maxillary and mandibular incisors (group 1), images suggestive of maxillary/mandibular incisor protrusion, and images suggestive of maxillary/mandibular incisor retrusion. To investigate the relationship between the pathologic inclination of the teeth and the thickness of the cortical plate, measurements were taken at the level of the cervical, middle and apical thirds of the root on the vestibular and lingual/palatal sides. CBCT was performed using a Planmeca ProMax 3DMid Ceph imaging unit (Planmeca Oy; Finland) with the patient's head positioned vertically. Field-of-view centering was carried out using visual light landmarks. The field of view covered the maxilla, the mandible, the maxillary sinus, and the orbit. Scanner settings: tube voltage of $90 \mathrm{kV}$, tube current of $12.5 \mathrm{~mA}$. The minimal informative slice thickness was $0.2 \mathrm{~mm}$; voxel size was $200 \mu \mathrm{m}$, effective dose was $90 \mu \mathrm{Sv}$. The field of view (FOV) size was $16 \times 16 \mathrm{~cm}$.

Obviously, the quality of CT images is superior to that of cephalograms in terms of edge sharpness. CT scans enable more accurate angular and linear measurements using landmark positions. For the purpose of the study, we selected sagittal-plane fragments on the obtained $16 \times 16$ images. Then, using the Schwartz method, the maxillary (NL) and mandibular $(\mathrm{ML})$ planes were delineated, and the inclination and position of incisors were defined as the angle between the long axis of the tooth and the maxillary/mandibular planes. The bottom outer and the inner upper angles were studied on the maxilla and mandible, respectively. For maxillary incisors, the angle of $70^{\circ}$ $+5^{\circ}$ was considered normal. The angle $\leq 70^{\circ}$ was interpreted as incisor protrusion; the angle $\geq 75^{\circ}$ was interpreted as incisor retrusion. For mandibular incisors, the angle of $90^{\circ}+5$ was interpreted as normal. The angle $<90^{\circ}$ was interpreted as retrusion, and the angle $>95^{\circ}$ was interpreted as protrusion. The obtained data were added to the patient's medical record.
The data were processed in Microsoft EXCEL and STATGRAPHICS Plus 5.1. We calculated the arithmetic mean $(\mathrm{M})$, the error of the mean $( \pm m)$, the mean arithmetic norm $(\mathrm{M})$, and the error of the norm $( \pm m)$. The differences were considered significant at $p<0.05$.

\section{RESULTS}

The following measurements were performed using the CBCT images of the front teeth:

1) for maxillary incisors, vestibular bone thickness at the cervical third of the root was measured as a distance between the outer cortical plate (Av) and the outer surface of the cervical third of the root (Bv); for mandibular incisors, vestibular bone thickness was measured as a distance between the outer cortical plate (Gv) and the outer surface of the cervical third of the root (Hv) (Fig. 1);

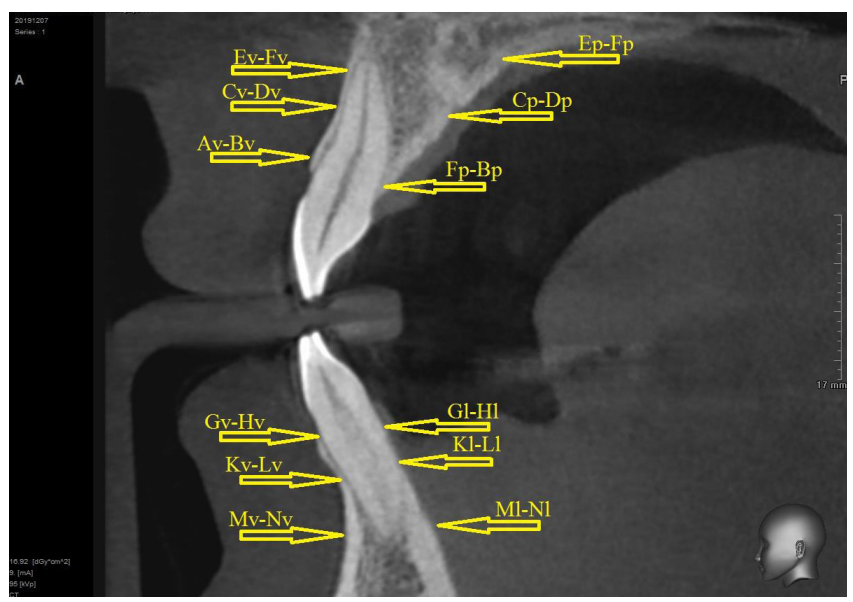

Fig. 1. Measurements on the upper and lower jaws

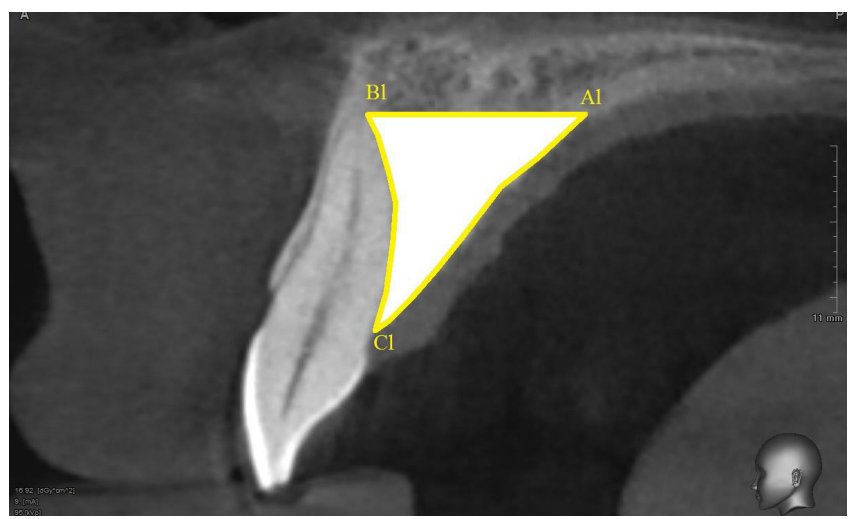

Fig. 2. Bone tissue area measurement

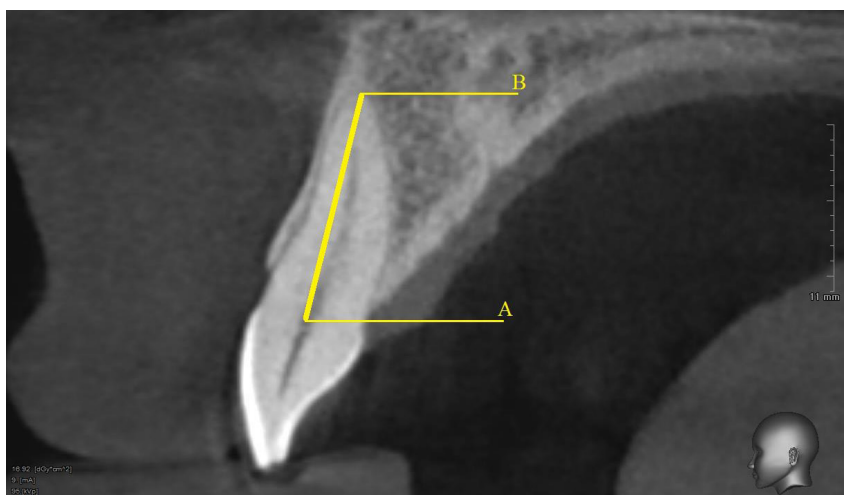

Fig. 3. Root-length measurement 
2) for maxillary incisors, vestibular bone thickness at the middle third of the root was measured as a distance from the outer cortical plate (Cv) to the outer surface of the middle third of the root (Dv); for mandibular incisors, vestibular bone thickness was measured as a distance between the outer cortical plate $(\mathrm{KI})$ and the outer surface of the middle third of the root (LV) (see Fig. 1);

3) for maxillary incisors, vestibular bone thickness at the apical third of the root was measured as a distance between the root apex (Ev) and the outer cortical plate (Fv); for mandibular incisors, the distance was measured from the root apex (Mv) to the outer cortical plate (Nv) (see Fig.1);

4) for maxillary incisors, palatal bone thickness at the cervical third of the root was measured as a distance from the outer cortical plate (Fp) to the lingual surface of the tooth root $(\mathrm{Bp})$ in the cervical region; for mandibular incisors, the distance was measured between the outer cortical plate (Gl) and the lingual surface of the cervical third of the root $(\mathrm{HI})$ (see Fig. 1);

5) for maxillary incisors, palatal bone thickness at the middle third of the root was measured as a distance between the outer cortical plate (Cp) and the lingual surface of the middle third of the root (Dp); for mandibular incisors, the distance was measured from the outer cortical plate $(\mathrm{KI})$ to the lingual surface of the middle third of the root (LI) (see Fig. 1);

6) for maxillary incisors, palatal bone thickness at the apical third of the root was measured as a distance between the tooth apex (Ep) and the outer cortical plate (Fp); for mandibular incisors, the distance was measured between the root apex (MI) and the outer cortical plate (NI) (see Fig. 1);

7) the area of lingual and palatal bone tissue was calculated as an area enclosed by the lines passing from the outer cortical plate at the root apex (Al) to the root apex (BI) to the upper (palatal) arch (Cl) (Fig. 2);

8) the length of the root was measured as a distance from its anatomical cervix (A) to the root apex (B) (Fig. 3);

9) the height of the interdental septum was measured as a distance between the septal peak $(A)$ and the perpendicular connecting the apices of the two adjacent teeth (B) (Fig. 4);

10) The degree of front teeth protrusion or retrusion was assessed from the obtained cephalometric radiography data: the angle U1-NL on the maxilla, where U1 is the line passing through the incisor long axis to the maxillary base plane (NL); and the angle L1-ML on the mandible, where L1 is the line passing through the long axis of the mandibular incisor to the mandibular base plane (ML).

Below, we offer a schematic representation of tooth movement in the upper and lower jaw bones for protruded and retruded teeth (Fig. 5, 6).

\section{Schematic representation of maxillary incisor retrusion}

The difference in angulation (a retruded vs normal tooth position) can be overcome by rotation around the fixedpoint $\mathrm{O}$ (the point of resistance); O needs to be linearly moved in the cervical and apical thirds of the root to a distance that offsets the difference in angulation expressed in degrees (Fig. 6). Given that BA AC and DC CA, the linear movement in the cervical third of the root can be described as follows:

$$
\text { Thickness } \underset{\text { vest }}{\text { Mailla }(1 / 3)}=\frac{1}{3} L_{\text {корн }} \times \tan \alpha, \text { where } \alpha=\angle \mathrm{BOA},
$$

the linear movement in the apical region can be described using the formula:

$$
\text { Thickness } \underset{\text { vest }}{\operatorname{Maxilla}(3 / 3)}=\frac{2}{3} L_{\text {корн }} \times \tan \alpha \text {, where } \alpha=\angle \mathrm{BOA}
$$

Retrusion of maxillary incisor movement can be described in the similar manner.

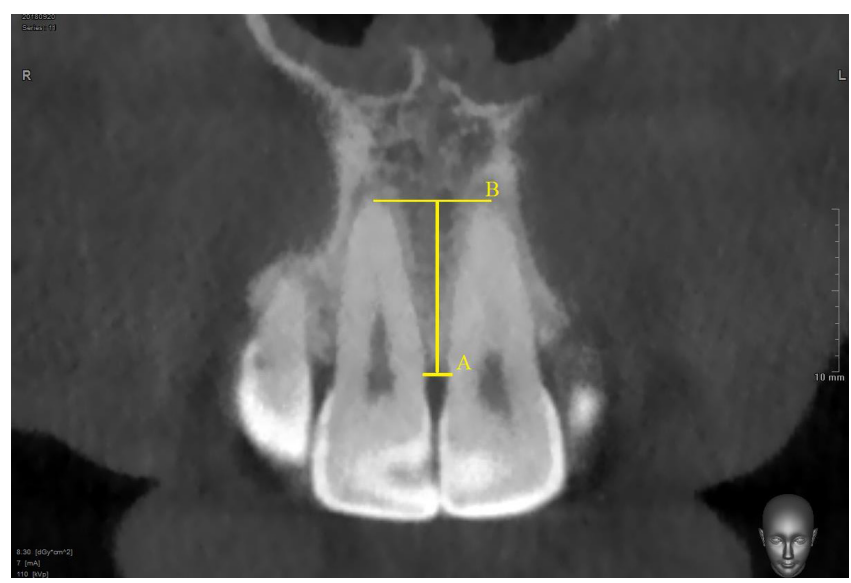

Fig. 4. Measurement of interdental septum height

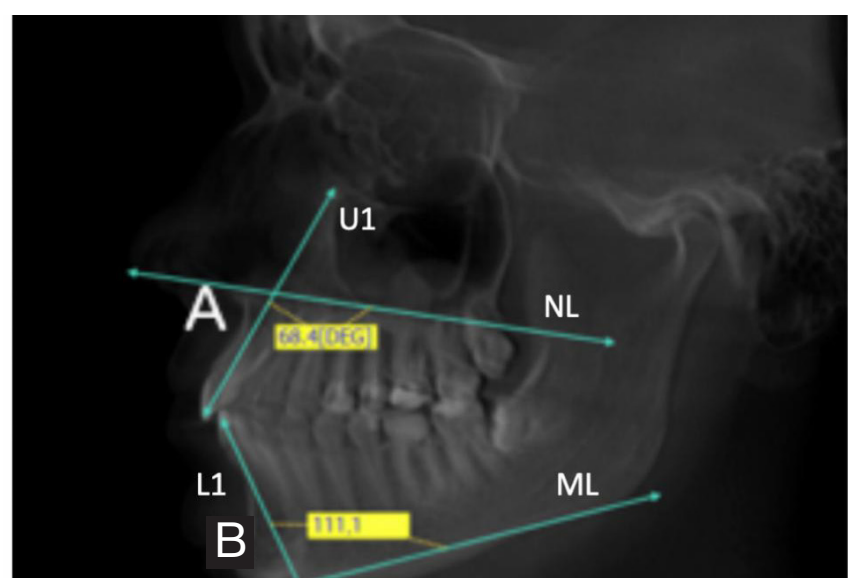

Fig. 5. Measurement of mandibular and maxillary incisor inclination

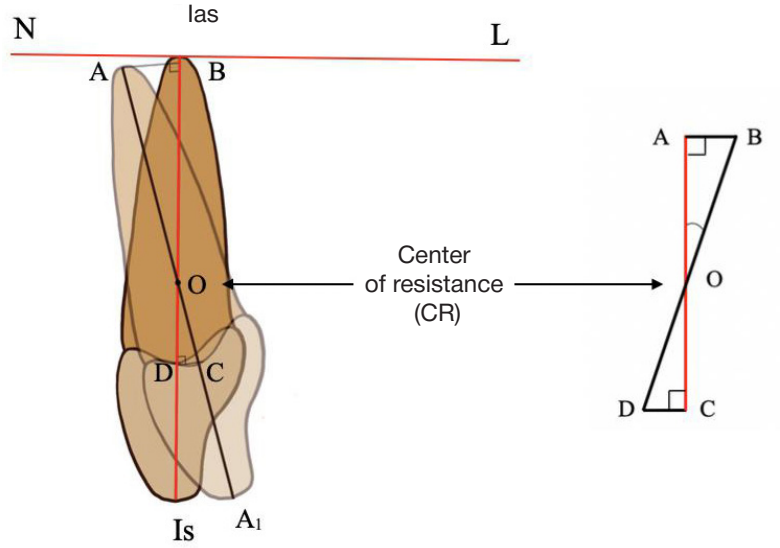

Fig. 6. The schematic representation of maxillary linear tooth movement in the surrounding bone tissue in the event of retrusion. Is is the cutting edge of the maxillary incisor; las is the apex of the maxillary incisor; las-Is is the incisor long axis; $\mathrm{NL}$ is a line in the maxillary plane; $\angle \mathrm{Is}-\mathrm{las}-\mathrm{NL}$ is the angle of maxillary incisor inclination; $\mathrm{BD}$ is a long tooth axis in the event of a normal (standard) incisor position; $A A$ is the long axis of a retruded incisor (actual position); $O$ is the center of resistance; $\angle B O A$ is an angle between the normal (standard) and actual axes; $\angle C O D$ is an angle between the normal (standard) and actual axes; AC means that the line BA is perpendicular to the line AC; $\angle$ Is-las $-\mathrm{L}(\angle \mathrm{Is}-\mathrm{las}$ to $\mathrm{NL})$ is an angle that characterizes the normal position of the incisor relative to the maxillary plane NL; las-ls is the long axis of a normally positioned (inclined) incisor; $A_{1}$ is the long axis of a retruded incisor; point $B$ is the projection of the apical point $A$ of a retruded maxillary incisor to the axis of a normally inclined tooth; point $D$ is the projection of the deepest point of the cementoenamel junction in the upper cervical region of the root of a retruded incisor to the long axis 12 of a normally inclined incisor; point $\mathrm{C}$ is a point in which the perpendicular drawn from the deepest point of the cementoenamel junction in the upper cervical region of a retruded tooth to the tooth axis of a normally inclined incisor and the line $A A 1 ; O$ is the center of resistance; $\angle \mathrm{BOA}=\angle \mathrm{COD}$ is an angle between the normal (standard) and actual axes; triangles $\mathrm{AOB}$ and $\mathrm{COD}$ are right-angled triangles 
Table 1. The universal table of linear tooth movement in the bone $(\mathrm{mm})$ depending on tooth inclination (degrees)

\begin{tabular}{|c|c|c|c|c|c|c|c|}
\hline & $1^{\circ}$ & $2^{\circ}$ & $3^{\circ}$ & $4^{\circ}$ & $5^{\circ}$ & $6^{\circ}$ & $7^{\circ}$ \\
\hline & \multicolumn{7}{|c|}{$9 \leqslant L^{*}<10$} \\
\hline $1 / 3$ & {$[0,052 \ldots 0,058]$} & {$[0,105 \ldots 0,116]$} & {$[0,157 \ldots 0,175]$} & {$[0,21 \ldots 0,233]$} & {$[0,262 \ldots 0,292]$} & {$[0,315 \ldots 0,35]$} & {$[0,368 \ldots 0,409]$} \\
\hline \multirow[t]{2}{*}{$3 / 3$} & {$[0,105 \ldots 0,116]$} & {$[0,21 \ldots 0,233]$} & {$[0,314 \ldots 0,349]$} & {$[0,42 \ldots 0,466]$} & {$[0,525 \ldots 0,583]$} & {$[0,631 \ldots 0,701]$} & {$[0,737 \ldots 0,819]$} \\
\hline & \multicolumn{7}{|c|}{$10 \leqslant L<11$} \\
\hline $1 / 3$ & {$[0,058 \ldots 0,064]$} & {$[0,116 \ldots 0,128]$} & {$[0,175 \ldots 0,192]$} & {$[0,233 \ldots 0,256]$} & {$[0,292 \ldots 0,321]$} & {$[0,35 \ldots 0,385]$} & {$[0,409 \ldots 0,45]$} \\
\hline \multirow[t]{2}{*}{$3 / 3$} & {$[0,116 \ldots 0,128]$} & {$[0,233 \ldots 0,256]$} & {$[0,349 \ldots 0,384]$} & {$[0,466 \ldots 0,513]$} & {$[0,583 \ldots 0,642]$} & {$[0,701 \ldots 0,771]$} & {$[0,819 \ldots 0,9]$} \\
\hline & \multicolumn{7}{|c|}{$11 \leqslant L<12$} \\
\hline $1 / 3$ & {$[0,064 \ldots 0,07]$} & {$[0,128 \ldots 0,14]$} & {$[0,192 \ldots 0,21]$} & {$[0,256 \ldots 0,28]$} & {$[0,321 \ldots 0,35]$} & {$[0,385 \ldots 0,42]$} & {$[0,45 \ldots 0,491]$} \\
\hline \multirow[t]{2}{*}{$3 / 3$} & {$[0,128 \ldots 0,14]$} & {$[0,256 \ldots 0,279]$} & {$[0,384 \ldots 0,419]$} & {$[0,513 \ldots 0,559]$} & {$[0,642 \ldots 0,7]$} & {$[0,771 \ldots 0,841]$} & {$[0,9 \ldots 0,982]$} \\
\hline & \multicolumn{7}{|c|}{$12 \leqslant L<13$} \\
\hline $1 / 3$ & {$[0,07 \ldots 0,076]$} & {$[0,14 \ldots 0,151]$} & {$[0,21 \ldots 0,227]$} & {$[0,28 \ldots 0,303]$} & {$[0,35 \ldots 0,379]$} & {$[0,42 \ldots 0,455]$} & {$[0,491 \ldots 0,532]$} \\
\hline \multirow[t]{2}{*}{$3 / 3$} & {$[0,14 \ldots 0,151]$} & {$[0,279 \ldots 0,303]$} & {$[0,419 \ldots 0,454]$} & {$[0,559 \ldots 0,606]$} & {$[0,7 \ldots 0,758]$} & {$[0,841 \ldots 0,911]$} & {$[0,982 \ldots 1,064]$} \\
\hline & \multicolumn{7}{|c|}{$13 \leqslant L<14$} \\
\hline $1 / 3$ & {$[0,076 \ldots 0,081]$} & {$[0,151 \ldots 0,163]$} & {$[0,227 \ldots 0,245]$} & {$[0,303 \ldots 0,326]$} & {$[0,379 \ldots 0,408]$} & {$[0,455 \ldots 0,49]$} & {$[0,532 \ldots 0,573]$} \\
\hline \multirow[t]{2}{*}{$3 / 3$} & {$[0,151 \ldots 0,163]$} & {$[0,303 \ldots 0,326]$} & {$[0,454 \ldots 0,489]$} & {$[0,606 \ldots 0,653]$} & {$[0,758 \ldots 0,817]$} & {$[0,911 \ldots 0,981]$} & {$[1,064 \ldots 1,146]$} \\
\hline & \multicolumn{7}{|c|}{$14 \leqslant L<15$} \\
\hline $1 / 3$ & {$[0,081 \ldots 0,087]$} & {$[0,163 \ldots 0,175]$} & {$[0,245 \ldots 0,262]$} & {$[0,326 \ldots 0,35]$} & {$[0,408 \ldots 0,437]$} & {$[0,49 \ldots 0,526]$} & {$[0,573 \ldots 0,614]$} \\
\hline \multirow[t]{2}{*}{$3 / 3$} & {$[0,163 \ldots 0,175]$} & {$[0,326 \ldots 0,349]$} & {$[0,489 \ldots 0,524]$} & {$[0,653 \ldots 0,699]$} & {$[0,817 \ldots 0,875]$} & {$[0,981 \ldots 1,051]$} & {$[1,146 \ldots 1,228]$} \\
\hline & \multicolumn{7}{|c|}{$15 \leqslant L<16$} \\
\hline $1 / 3$ & {$[0,087 \ldots 0,093]$} & {$[0,175 \ldots 0,186]$} & {$[0,262 \ldots 0,28]$} & {$[0,35 \ldots 0,373]$} & {$[0,437 \ldots 0,467]$} & {$[0,526 \ldots 0,561]$} & {$[0,614 \ldots 0,655]$} \\
\hline \multirow[t]{2}{*}{$3 / 3$} & {$[0,175 \ldots 0,186]$} & {$[0,349 \ldots 0,372]$} & {$[0,524 \ldots 0,559]$} & {$[0,699 \ldots 0,746]$} & {$[0,875 \ldots 0,933]$} & {$[1,051 \ldots 1,121]$} & {$[1,228 \ldots 1,31]$} \\
\hline & \multicolumn{7}{|c|}{$16 \leqslant L<17$} \\
\hline $1 / 3$ & {$[0,093 \ldots 0,099]$} & {$[0,186 \ldots 0,198]$} & {$[0,28 \ldots 0,297]$} & {$[0,373 \ldots 0,396]$} & {$[0,467 \ldots 0,496]$} & {$[0,561 \ldots 0,596]$} & {$[0,655 \ldots 0,696]$} \\
\hline \multirow[t]{2}{*}{$3 / 3$} & {$[0,186 \ldots 0,198]$} & {$[0,372 \ldots 0,396]$} & {$[0,559 \ldots 0,594]$} & {$[0,746 \ldots 0,793]$} & {$[0,933 \ldots 0,992]$} & {$[1,121 \ldots 1,191]$} & {$[1,31 \ldots 1,392]$} \\
\hline & \multicolumn{7}{|c|}{$17 \leqslant L<18$} \\
\hline $1 / 3$ & {$[0,099 \ldots 0,105]$} & {$[0,198 \ldots 0,21]$} & {$[0,297 \ldots 0,314]$} & {$[0,396 \ldots 0,42]$} & {$[0,496 \ldots 0,525]$} & {$[0,596 \ldots 0,631]$} & {$[0,696 \ldots 0,737]$} \\
\hline \multirow[t]{2}{*}{$3 / 3$} & {$[0,198 \ldots 0,209]$} & {$[0,396 \ldots 0,419]$} & {$[0,594 \ldots 0,629]$} & {$[0,793 \ldots 0,839]$} & {$[0,992 \ldots 1,05]$} & {$[1,191 \ldots 1,261]$} & {$[1,392 \ldots 1,473]$} \\
\hline & \multicolumn{7}{|c|}{$18 \leqslant L<19$} \\
\hline $1 / 3$ & {$[0,105 \ldots 0,111]$} & {$[0,21 \ldots 0,221]$} & {$[0,314 \ldots 0,332]$} & {$[0,42 \ldots 0,443]$} & {$[0,525 \ldots 0,554]$} & {$[0,631 \ldots 0,666]$} & {$[0,737 \ldots 0,778]$} \\
\hline \multirow[t]{2}{*}{$3 / 3$} & {$[0,209 \ldots 0,221]$} & {$[0,419 \ldots 0,442]$} & {$[0,629 \ldots 0,664]$} & {$[0,839 \ldots 0,886]$} & {$[1,05 \ldots 1,108]$} & {$[1,261 \ldots 1,331]$} & {$[1,473 \ldots 1,555]$} \\
\hline & \multicolumn{7}{|c|}{$19 \leqslant L<20$} \\
\hline $1 / 3$ & {$[0,111 \ldots 0,116]$} & {$[0,221 \ldots 0,233]$} & {$[0,332 \ldots 0,349]$} & {$[0,443 \ldots 0,466]$} & {$[0,554 \ldots 0,583]$} & {$[0,666 \ldots 0,701]$} & {$[0,778 \ldots 0,819]$} \\
\hline $3 / 3$ & {$[0,221 \ldots 0,233]$} & {$[0,442 \ldots 0,466]$} & {$[0,664 \ldots 0,699]$} & {$[0,886 \ldots 0,932]$} & {$[1,108 \ldots 1,167]$} & {$[1,331 \ldots 1,401]$} & {$[1,555 \ldots 1,637]$} \\
\hline
\end{tabular}

Note: $L$ is root length.

\section{Schematic representation of mandibular incisor retrusion}

The linear movement of mandibular incisors in the event or protrusion or retrusion are described using the same approach, but the mandible is designated as ML (Fig. 7).

\section{RESULTS}

Using the CBCT images of patients with normally inclined teeth, we discovered that vestibular bone thickness at the cervical third of the root of the maxillary central incisors was $1.04 \pm$ $0.04 \mathrm{~mm}$ for tooth 1.1 and $0.96 \pm 0.07 \mathrm{~mm}$ for tooth 2.1. For the maxillary lateral incisors, the figures were as follows: 0.81 $\pm 0.04 \mathrm{~mm}$ for tooth 1.2 and $0.84 \pm 0.09 \mathrm{~mm}$ for tooth 2.2. For the maxillary canines, the following values were obtained: $0.91 \pm 0.06 \mathrm{~mm}$ for tooth 1.3 and $0.84 \pm 0.09 \mathrm{~mm}$ for tooth

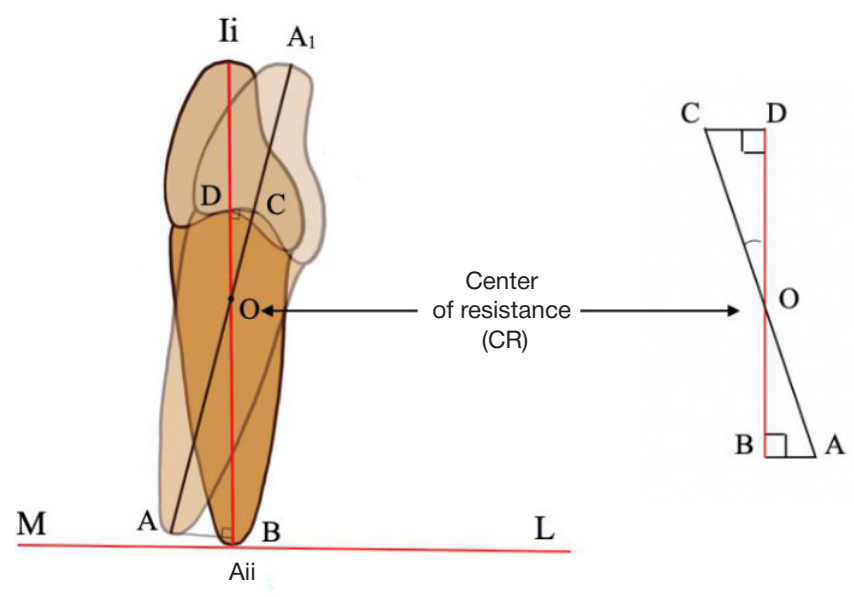

Fig. 7. Schematic representation of mandibular incisor retrusion 
Table 2. The universal table of linear tooth movement in the bone $(\mathrm{mm})$ depending on tooth inclination (degrees)

\begin{tabular}{|c|c|c|c|c|c|c|c|c|}
\hline & $8^{\circ}$ & $9^{\circ}$ & $10^{\circ}$ & $11^{\circ}$ & $12^{\circ}$ & $13^{\circ}$ & $14^{\circ}$ & $15^{\circ}$ \\
\hline & \multicolumn{8}{|c|}{$9 \leqslant \mathrm{~L}^{*}<10$} \\
\hline $1 / 3$ vest & {$[0,422 \ldots 0,468]$} & {$[0,475 \ldots 0,528]$} & {$[0,529 \ldots 0,588]$} & {$[0,583 \ldots 0,648]$} & {$[0,638 \ldots 0,709]$} & {$[0,693 \ldots 0,77]$} & {$[0,748 \ldots 0,831]$} & {$[0,804 \ldots 0,893]$} \\
\hline \multirow[t]{2}{*}{$3 / 3$ vest } & {$[0,843 \ldots 0,937]$} & {$[0,95 \ldots 1,056]$} & {$[1,058 \ldots 1,176]$} & {$[1,166 \ldots 1,296]$} & {$[1,275 \ldots 1,417]$} & {$[1,385 \ldots 1,539]$} & {$[1,496 \ldots 1,662]$} & {$[1,608 \ldots 1,786]$} \\
\hline & \multicolumn{8}{|c|}{$10 \leqslant L<11$} \\
\hline $1 / 3$ vest & {$[0,468 \ldots 0,515]$} & {$[0,528 \ldots 0,581]$} & {$[0,588 \ldots 0,647]$} & {$[0,648 \ldots 0,713]$} & {$[0,709 \ldots 0,779]$} & {$[0,77 \ldots 0,847]$} & {$[0,831 \ldots 0,914]$} & {$[0,893 \ldots 0,982]$} \\
\hline \multirow[t]{2}{*}{$3 / 3$ vest } & {$[0,937 \ldots 1,031]$} & {$[1,056 \ldots 1,161]$} & {$[1,176 \ldots 1,293]$} & {$[1,296 \ldots 1,425]$} & {$[1,417 \ldots 1,559]$} & {$[1,539 \ldots 1,693]$} & {$[1,662 \ldots 1,828]$} & {$[1,786 \ldots 1,965]$} \\
\hline & \multicolumn{8}{|c|}{$11 \leqslant L<12$} \\
\hline $1 / 3$ vest & {$[0,515 \ldots 0,562]$} & {$[0,581 \ldots 0,634]$} & {$[0,647 \ldots 0,705]$} & {$[0,713 \ldots 0,778]$} & {$[0,779 \ldots 0,85]$} & {$[0,847 \ldots 0,923]$} & {$[0,914 \ldots 0,997]$} & {$[0,982 \ldots 1,072]$} \\
\hline \multirow[t]{2}{*}{$3 / 3$ vest } & {$[1,031 \ldots 1,124]$} & {$[1,161 \ldots 1,267]$} & {$[1,293 \ldots 1,411]$} & {$[1,425 \ldots 1,555]$} & {$[1,559 \ldots 1,7]$} & {$[1,693 \ldots 1,847]$} & {$[1,828 \ldots 1,995]$} & {$[1,965 \ldots 2,144]$} \\
\hline & \multicolumn{8}{|c|}{$12 \leqslant L<13$} \\
\hline $1 / 3$ vest & {$[0,562 \ldots 0,609]$} & {$[0,634 \ldots 0,686]$} & {$[0,705 \ldots 0,764]$} & {$[0,778 \ldots 0,842]$} & {$[0,85 \ldots 0,921]$} & {$[0,923 \ldots 1]$} & {$[0,997 \ldots 1,08]$} & {$[1,072 \ldots 1,161]$} \\
\hline \multirow[t]{2}{*}{$3 / 3$ vest } & {$[1,124 \ldots 1,218]$} & {$[1,267 \ldots 1,373]$} & {$[1,411 \ldots 1,528]$} & {$[1,555 \ldots 1,685]$} & {$[1,7 \ldots 1,842]$} & {$[1,847 \ldots 2,001]$} & {$[1,995 \ldots 2,161]$} & {$[2,144 \ldots 2,322]$} \\
\hline & \multicolumn{8}{|c|}{$13 \leqslant L<14$} \\
\hline $1 / 3$ vest & {$[0,699 \ldots 0,795]$} & {$[0,686 \ldots 0,739]$} & {$[0,764 \ldots 0,823]$} & {$[0,842 \ldots 0,907]$} & {$[0,921 \ldots 0,992]$} & {$[1 \ldots 1,077]$} & {$[1,08 \ldots 1,164]$} & {$[1,161 \ldots 1,25]$} \\
\hline \multirow[t]{2}{*}{$3 / 3$ vest } & {$[1,218 \ldots 1,312]$} & {$[1,373 \ldots 1,478]$} & {$[1,528 \ldots 1,646]$} & {$[1,685 \ldots 1,814]$} & {$[1,842 \ldots 1,984]$} & {$[2,001 \ldots 2,155]$} & {$[2,161 \ldots 2,327]$} & {$[2,322 \ldots 2,501]$} \\
\hline & \multicolumn{8}{|c|}{$14 \leqslant L<15$} \\
\hline $1 / 3$ vest & {$[0,656 \ldots 0,703]$} & {$[0,739 \ldots 0,792]$} & {$[0,823 \ldots 0,882]$} & {$[0,907 \ldots 0,972]$} & {$[0,992 \ldots 1,063]$} & {$[1,077 \ldots 1,154]$} & {$[1,164 \ldots 1,247]$} & {$[1,25 \ldots 1,34]$} \\
\hline \multirow[t]{2}{*}{$3 / 3$ vest } & {$[1,312 \ldots 1,405]$} & {$[1,478 \ldots 1,584]$} & {$[1,646 \ldots 1,763]$} & {$[1,814 \ldots 1,944]$} & {$[1,984 \ldots 2,126]$} & {$[2,155 \ldots 2,309]$} & {$[2,327 \ldots 2,493]$} & {$[2,501 \ldots 2,679]$} \\
\hline & \multicolumn{8}{|c|}{$15 \leqslant L<16$} \\
\hline $1 / 3$ vest & {$[0,703 \ldots 0,75]$} & {$[0,792 \ldots 0,845]$} & {$[0,882 \ldots 0,94]$} & {$[0,972 \ldots 1,037]$} & {$[1,063 \ldots 1,134]$} & {$[1,154 \ldots 1,231]$} & {$[1,247 \ldots 1,33]$} & {$[1,34 \ldots 1,429]$} \\
\hline \multirow[t]{2}{*}{$3 / 3$ vest } & {$[1,405 \ldots 1,499]$} & {$[1,584 \ldots 1,689]$} & {$[1,763 \ldots 1,881]$} & {$[1,944 \ldots 2,073]$} & {$[2,126 \ldots 2,267]$} & {$[2,309 \ldots 2,463]$} & {$[2,493 \ldots 2,659]$} & {$[2,679 \ldots 2,858]$} \\
\hline & \multicolumn{8}{|c|}{$16 \leqslant L<17$} \\
\hline $1 / 3$ vest & {$[0,75 \ldots 0,796]$} & {$[0,845 \ldots 0,898]$} & {$[0,94 \ldots 0,999]$} & {$[1,037 \ldots 1,101]$} & {$[1,134 \ldots 1,204]$} & {$[1,231 \ldots 1,308]$} & {$[1,33 \ldots 1,413]$} & {$[1,429 \ldots 1,518]$} \\
\hline \multirow[t]{2}{*}{$3 / 3$ vest } & {$[1,499 \ldots 1,593]$} & {$[1,689 \ldots 1,795]$} & {$[1,881 \ldots 1,998]$} & {$[2,073 \ldots 2,203]$} & {$[2,267 \ldots 2,409]$} & {$[2,463 \ldots 2,617]$} & {$[2,659 \ldots 2,826]$} & {$[2,858 \ldots 3,037]$} \\
\hline & \multicolumn{8}{|c|}{$17 \leqslant L<18$} \\
\hline $1 / 3$ vest & {$[0,796 \ldots 0,843]$} & {$[0,898 \ldots 0,95]$} & {$[0,999 \ldots 1,058]$} & {$[1,101 \ldots 1,166]$} & {$[1,204 \ldots 1,275]$} & {$[1,308 \ldots 1,385]$} & {$[1,413 \ldots 1,496]$} & {$[1,518 \ldots 1,608]$} \\
\hline \multirow[t]{2}{*}{$3 / 3$ vest } & {$[1,593 \ldots 1,686]$} & {$[1,795 \ldots 1,901]$} & {$[1,998 \ldots 2,116]$} & {$[2,203 \ldots 2,333]$} & {$[2,409 \ldots 2,551]$} & {$[2,617 \ldots 2,77]$} & {$[2,826 \ldots 2,992]$} & {$[3,037 \ldots 3,215]$} \\
\hline & \multicolumn{8}{|c|}{$18 \leqslant L<19$} \\
\hline $1 / 3$ vest & {$[0,843 \ldots 0,89]$} & {$[0,95 \ldots 1,003]$} & {$[1,058 \ldots 1,117]$} & {$[1,166 \ldots 1,231]$} & {$[1,275 \ldots 1,346]$} & {$[1,385 \ldots 1,462]$} & {$[1,496 \ldots 1,579]$} & {$[1,608 \ldots 1,697]$} \\
\hline \multirow[t]{2}{*}{$3 / 3$ vest } & {$[1,686 \ldots 1,78]$} & {$[1,901 \ldots 2,006]$} & {$[2,116 \ldots 2,233]$} & {$[2,333 \ldots 2,462]$} & {$[2,551 \ldots 2,692]$} & {$[2,77 \ldots 2,924]$} & {$[2,992 \ldots 3,158]$} & {$[3,215 \ldots 3,394]$} \\
\hline & \multicolumn{8}{|c|}{$19 \leqslant L<20$} \\
\hline $1 / 3$ vest & {$[0,89 \ldots 0,937]$} & {$[1,003 \ldots 1,056]$} & {$[1,117 \ldots 1,176]$} & {$[1,231 \ldots 1,296]$} & {$[1,346 \ldots 1,417]$} & {$[1,462 \ldots 1,539]$} & {$[1,579 \ldots 1,662]$} & {$[1,697 \ldots 1,786]$} \\
\hline $3 / 3$ vest & {$[1,78 \ldots 1,874]$} & {$[2,006 \ldots 2,112]$} & {$[2,233 \ldots 2,351]$} & {$[2,462 \ldots 2,592]$} & {$[2,692 \ldots 2,834]$} & {$[2,924 \ldots 3,078]$} & {$[3,158 \ldots 3,324]$} & {$[3,394 \ldots 3,573]$} \\
\hline
\end{tabular}

Table 3. Comparison of alveolar bone parameters surrounding the tooth 3.3. in the events of its protrusion and retrusion

2.3. Vestibular bone thickness at the apical third of the root of the maxillary central incisors was as follows: $0.95 \pm 0.04 \mathrm{~mm}$ for tooth $1.1,0.71 \pm 0.04 \mathrm{~mm}$ for tooth $2.1,1.05 \pm 0.06 \mathrm{~mm}$ for tooth $1.2,1.31 \pm 0.08 \mathrm{~mm}$ for tooth $2.2,1.22 \pm 0.06 \mathrm{~mm}$ for tooth $1.3,1.31 \pm 0.08 \mathrm{~mm}$ for tooth 2.3. Vestibular bone thickness at the cervical third of mandibular incisors was $1.12 \pm 0.04 \mathrm{~mm}$ for tooth $3.1,1.26 \pm 0.06 \mathrm{~mm}$ for tooth 4.1 $0.89 \pm 0.07 \mathrm{~mm}$ for tooth $3.2,1.18 \pm 0.03 \mathrm{~mm}$ for tooth 4.2 , $0.94 \pm 0.03 \mathrm{~mm}$ for tooth $3.3,1.26 \pm 0.12 \mathrm{~mm}$ for tooth 4.3. At the apical third, bone thickness was $3.35 \pm 0.04 \mathrm{~mm}$ for tooth $3.1,2.44 \pm 0.04 \mathrm{~mm}$ for tooth $4.1,2.86 \pm 0.05 \mathrm{~mm}$ for tooth $3.2,2.88 \pm 0.07 \mathrm{~mm}$ for tooth $4.2,3.53 \pm 0,21 \mathrm{~mm}$ for tooth 3.3, $2.81 \pm 0.06 \mathrm{~mm}$ for tooth 4.3 .

Thus, the CBCT images of pathologically inclined teeth revealed that the most pronounced bone deficit was observed in the maxilla around the cervical third of the root of the protruded central and lateral incisors (20\% and 16\%, respectively, relative to the control group). In the mandible, bone deficit around the apical third of the protruded central and lateral incisors was $64 \%$ and $16 \%$, respectively. For the canine teeth, bone deficit was $22 \%$ relative to the control group. Bone thickness around the cervical third of the root of the retruded maxillary frontal teeth was 36\% less than in the control group; for the maxillary lateral incisors, bone deficit reached $24 \%$. For the maxillary canine teeth, alveolar bone thickness around the cervical third of the root was $31 \%$ less than in the control group. In the mandible, vestibular bone deficit around the cervical third of the root was $27 \%, 38.5 \%$ and $33 \%$ for the central incisors, lateral incisors and canine teeth, respectively.

Thus, both vestibular and palatal bone deficit was observed at the cervical third of the root for two groups of upper teeth, being the most pronounced around the retruded incisors. In the mandible, the loss of vestibular bone thickness at the cervical third of the retruded frontal teeth was more pronounced; however, the loss of lingual bone thickness at the cervical third of the root was more pronounced for protruded vs. retruded 


\begin{tabular}{|c|c|c|c|}
\hline Area of measurements $(\mathrm{mm})$ & Protrusion & Retrusion & Significance \\
\hline $\begin{array}{c}\text { BT } \\
\text { vest. } 1 / 3\end{array}$ & $0,73 \pm 0,10$ & $0,31 \pm 0,05$ & $p<0,001$ \\
\hline $\begin{array}{c}\text { BT } \\
\text { vest. } 3 / 3\end{array}$ & $3,39 \pm 0,20$ & $2,97 \pm 0,12$ & $p>0,05$ \\
\hline$L_{\text {root }}$ & $13,88 \pm 0,24$ & $16,71 \pm 0,19$ & $p<0,001$ \\
\hline
\end{tabular}

Note: BT stands for bone thickness; $p<0.05$ indicates statistically significant differences.

teeth. The detected significant differences in vestibular bone thickness at the cervical third of the root of the studied frontal teeth suggest that there are potential risk areas of bone loss in patients with retrusion and protrusion undergoing orthodontic treatment.

Tables 1 and 2 summarize the results of our study and contain information about the root length for the maxillary and mandibular frontal teeth, as well as vestibular and palatal/lingual bone thickness at the cervical and apical thirds of their roots. The table allows estimating the bone volume needed to change tooth inclination from $1^{\circ}$ to $15^{\circ}$. Our calculations rely on the root length of a studied tooth as a starting point. While planning a desired change in tooth inclination, an orthodontist can use the data from the Tables to make sure that there is sufficient bone volume around the cervical and apical thirds of the root.

Information provided in the Tables will help to avoid bone resorption in the area of bone deficit during orthodontic treatment and prevent the root from getting beyond the cortical bone.

How to use the Tables:

1) measure the length of the tooth root and the vestibular/ palatal bone thickness at the cervical and apical thirds;

2) consult the table for the recommended bone thickness calculated for the already changed vestibulo-oral tooth inclination;

3) using the obtained data, plan the movement of the frontal teeth.

Below, we provide an example of changes to the vestibulooral inclination of the tooth 3.3. Information about bone thickness for a protruded or retruded tooth 3.3 is provided in the Tables. Table 3 shows the results of measurements for this tooth: root length $(\mathrm{L}, \mathrm{mm})$, vestibular bone thickness at the cervical third of the root (TKT vest. 1/3, mm), and vestibular bone thickness at the apical third (TKT vest. $3 / 3, \mathrm{~mm}$ ).

Thus, when using analyzing bone thickness around the cervical third of the root of tooth 3.3. in the event of protrusion or retrusion, one can plan a safe change to tooth inclination by consulting the Tables, which demonstrate that the length of the root falls withing the range from 13 to $14 \mathrm{~mm}$. So, the inclination of the tooth 3.3. can be safely changed by 9o, considering the amount of bone around the cervical third of the root. For this tooth, there is no bone deficit around the apical third of the root. For the retruded tooth 3.3, the length of the root will range from 16 to $17 \mathrm{~mm}$, so one can safely change the inclination of this tooth by 30 ; creating a more pronounced inclination is prevented by bone deficit in this area. Bone thickness is sufficient around the apical third of the root.

\section{DISCUSSION}

There is a wealth of literature describing the thickness of the cortical and alveolar bones in patients with pathologically inclined teeth. A 2007 study used CT images to describe the position of mandibular incisors, their root apices and the condition of bone tissue in patients with retrusive occlusion and pathological tooth inclination. The researchers measured distances from the root apex to the inner contour of the cortical bone on the vestibular and lingual surfaces, tooth inclinations and the thickness of the surrounding bone. They concluded that there was an association between the vestibular bone angle and tooth inclination, the lingual bone angle and the incisor inclination angle [12]. In 2009, another team of researchers studied dental bone thickness; however, they did not report the association between the incisor angle and the distance from the vestibular and lingual cortical plates to root apices. The study confirms the association between incisor inclination and the position of tooth apices, as well as the morphology of the bone surrounding the tooth [13].

\section{CONCLUSIONS}

CBCT has a better diagnostic capacity, with its minimal slice thickness of $0.2 \mathrm{~mm}$, than multislice spiral CT, which offers the slice thickness of only $1 \mathrm{~mm}$ and therefore is diagnostically unacceptable when it comes to dentofacial examination. The effective dose delivered by CBCT is $61-134 \mu \mathrm{Sv}$; the effective dose during an orthopantomography scan is 4 times lower, whereas the effective dose delivered by multislice spiral CT is 1.5-12.3 times higher than during a CBCT scan. CBCT is an advantageous diagnostic modality in terms of contour and object sharpness and enables more accurate linear and angular measurements using landmark positions. Our universal tables allow the orthodontist to estimate bone thickness at different levels of the tooth root in order to ensure a safe change in tooth inclination in patients with pathologically inclined teeth. When used in combination, our tables and CBCT make it possible to assess the safety of tooth movement and the necessary thickness of bone tissue at different levels of the tooth root. The tables are a huge aid in dental diagnosis and orthodontic treatment planning, helping to assess the safety of movement frontal teeth depending on the thickness of the surrounding bone.

\section{References}

1. Singatullina DR, Hamitova NH. Harakter techenija retencionnogo perioda u podrostkov posle ortodonticheskogo lechenija $v$ zavisimosti ot sostojanija vegetativnoj nervnoj sistemy. Kazanskij medicinskii zhurnal. 2012; 9 (4): 651-3.

2. Chibisova MA, Orehova MA, Serova NV. Kliniko-rentgenologicheskaja harakteristika i algoritm diagnosticheskogo issledovanija na konusno-luchevom komp'juternom tomografe pacientov $s$ zabolevanijami parodonta. Luchevaja diagnostika i terapija. 2014;
4: 18-37.

3. Nanda R. Biomihanika i jestetika $\vee$ klinicheskoj medicine. M. MEDpress-inform, 2009; $388 \mathrm{~s}$.

4. Vanden Bulcke MM, Dermaut LR, Sachdeva RC. Location of centers of resistance for anterior teeth during retraction using the laser reflection technique. Am J Orthod Dentofacial Orthop. 1987; 91: 375-84.

5. Dathe H, Nägerl H, Kubein-Meesenburg D. A caveat concerning 
center of resistance. Journal of Dental Biomechanics. 2013; 4: 1-7.

6. Dubinin AL, Nyashin Yul, Osipenko MA, Elovikova AN, Nyashin MYu Optimizacija ortodonticheskogo peremeshhenija zubov. Rossijskij zhurnal biomehaniki. 2016; 20 (1): 37-47.

7. Shkarin W, Domenyuk DA, Dmitrienko SV, Porfiriadis MP, Fomin IV, Borodina VA. Sovremennye podhody k opredeleniju ugla inklinacii zubov pri diagnostike i planirovanii ortodonticheskogo lechenija. Kubanskij nauchnyj medicinskij vestnik. 2018; 25 (2): 156-65.

8. Vedeshina YeG. Optimizacija sovremennyh metodov diagnostiki i lechenija pacientov s anomalijami i deformacijami zubocheljustnyh dug [dissertaciya]. Pjatigorsk, 2019; 371 s.

9. Domenyuk DA, Garazha IS, Karslieva AG, Vedeshina YeG, i dr. Primenenie dostizhenij cheljustno-licevoj rentgenologii v lechenii zubocheljustnyh anomalij Aktual'nye voprosy klinicheskoj stomatologii. $\vee$ sbornike nauchnyh rabot pod redakciej N. N.
Garazhi. Stavropol': Izd-vo StGMU, 2015; s. 119-23.

10. Vansvanov AM, llyasova AM, llyasov AM. Rentgenograficheskaja i komp'juterno-tomograficheskaja diagnostika patologii cheljustnolicevoj oblasti. Vestnik KazNMU. 2014; 3 (2).

11. Dubinin AL, Osipenko MA, Nyashin Yul. Primenenie cifrovyh tehnologij pri biomehanicheskom modelirovanii ortodonticheskogo peremeshhenija zubov. Rossijskij zhurnal biomehaniki. 2019; 23 (3): 359-74.

12. Yamada C, Kitai N, Kakimoto N, Muraami S, Furukawa S, Takada K. Spatial relationships between the mandibular central incisor and associated alveolar bone in adults with mandibular prognathism. Angle Orthod. 2007; 77: 766-72.

13. Yu Q, Pan X, Ji G, Shen $G$. The association between lower incisal inclination and morphology of the supporting alveolar bone - a cone-beam CT study. Int J Oral Sci. 2009; 1: 217-23.

\section{Литература}

1. Сингатуллина Д. Р., Хамитова Н. Х. Характер течения ретенционного периода у подростков после ортодонтического лечения в зависимости от состояния вегетативной нервной системы. Казанский медицинский журнал. 2012; 9 (4): 651-3.

2. Чибисова М. А., Орехова М. А., Серова Н. В. Клиникорентгенологическая характеристика и алгоритм диагностического исследования на конусно-лучевом компьютерном томографе пациентов с заболеваниями пародонта. Лучевая диагностика и терапия. 2014; 4: 18-37.

3. Нанда Р. Биомиханика и эстетика в клинической медицине. М.: МЕДпресс-информ, 2009; 388 с.

4. Vanden Bulcke MM, Dermaut LR, Sachdeva RC. Location of centers of resistance for anterior teeth during retraction using the laser reflection technique. Am J Orthod Dentofacial Orthop. 1987; 91: 375-84.

5. Dathe H, Nägerl H, Kubein-Meesenburg D. A caveat concerning center of resistance. Journal of Dental Biomechanics. 2013; 4 : $1-7$.

6. Дубинин А. Л., Няшин Ю. И., Осипенко М. А., Еловикова А. Н., Няшин М. Ю. Оптимизация ортодонтического перемещения зубов. Российский журнал биомеханики. 2016; 20 (1): 37-47.

7. Шкарин В. В., Доменюк Д. А., Дмитриенко С. В., Порфириадис М. П., Фомин И. В., Бородина В. А. Современные подходы к определению угла инклинации зубов при диагностике и планировании ортодонтического лечения. Кубанский

научный медицинский вестник. 2018; 25 (2): 156-165.

8. Ведешина Э. Г. Оптимизация современных методов диагностики и лечения пациентов с аномалиями и деформациями зубочелюстных дуг [диссертация]. Пятигорск, 2019; 371 с.

9. Доменюк Д. А., Гаража И. С., Карслиева А. Г., Ведешина Э. Г. и др. Применение достижений челюстно-лицевой рентгенологии в лечении зубочелюстных аномалий Актуальные вопросы клинической стоматологии. В сборнике научных работ под редакцией Н. Н. Гаражи. Ставрополь: Изд-во СтГМУ, 2015; с. 119-23.

10. Вансванов А. М., Ильясова А. М., Ильясов А. М. Рентгенографическая и компьютерно-томографическая диагностика патологии челюстно-лицевой области. Вестник КазНМУ. 2014; 3 (2).

11. Дубинин А. Л., Осипенко М. А., Няшин Ю. И. Применение цифровых технологий при биомеханическом моделировании ортодонтического перемещения зубов. Российский журнал биомеханики. 2019; 23 (3): 359-74.

12. Yamada C, Kitai N, Kakimoto N, Muraami S, Furukawa S, Takada K. Spatial relationships between the mandibular central incisor and associated alveolar bone in adults with mandibular prognathism. Angle Orthod. 2007; 77: 766-72.

13. Yu Q, Pan X, Ji G, Shen $G$. The association between lower incisal inclination and morphology of the supporting alveolar bone - a cone-beam CT study. Int J Oral Sci. 2009; 1: 217-23. 